\title{
LEGAL PROTECTION AGAINST CHILDREN VICTIMS OF SEXUAL VIOLENCE IN THE DIRECTORATE GENERAL CRIMINAL AGENCY-POLDA BALI
}

\author{
Komang Suartana, Faculty of Law and Social Science Undiknas University \\ e-mail: komangsuartana71@gmail.com \\ I Made Wirya Darma, Faculty of Law and Social Science Undiknas University \\ e-mail: wiryadarma@undiknas.ac.id
}

doi: https://doi.org/10.24843/KS.2020.v08.i12.p13

\begin{abstract}
This study aims to analyze the legal protection provided for children as a victim of sexual violence at the Bali Regional General Criminal Investigation Directorate and any legal action could be taken if the legal protection for child victims is not implemented. This is an empirical juridical legal study. The results show that the legal protection provided to children as a victim of sexual violence includes the humane treatment of children following the dignity and rights of the child, the provision of special assistants for children from an early age from Social Service Workers and others. The legal action is taken if the legal protection over the child victims is in the investigation stage, the victim feels that he has not received any legal service or protection from the investigator in terms of the rights of the child as a victim and his family can report to his superiors so that the investigator's performance can be evaluated to provide a maximal legal service and protection for the child.
\end{abstract}

Keywords: Legal Protection, Child, Sexual Violence, Polda Bali

\section{Introduction}

The problem of violent crime has become a serious problem faced by almost every nation and state nowadays. Various discussions, seminars, and scientific meetings were held to find solutions that were considered appropriate regarding the crimes that were happening and troubling the public. In daily life, the problem of violence is associated with criminal cases that tend to be more violent or brutal. Theft, looting, and rape accompanied by violence in addition to murder in various sadistic forms, add to the list of the agenda for any discussion about violence. ${ }^{1}$

It indicates that violent crime seems to be experiencing a fluctuation in society. The problem of crime remains a frightening specter for society, whose emergence is often unpredicted or suddenly occurs in any environment or community that previously had never been predicted to give rise to crimes categorized as aggravation.

In a community that was previously known to have noble teachings, which popularized the principles of civilized and socially related life that uphold moral and religious values, it is not always happening as it should be. It means that people who have the teachings of noble civilization are quite prone to creating various modes of crime. Not a few social, political, economic, religious, and legal actors are trapped in the defiance of high values (values disobedience).

For instance, in Indonesia as a country with the philosophy of Pancasila and the 1945 State Constitution of the Republic of Indonesia, and also is predominantly Muslim,

1 Nashir, Haedar. Agama E krisis kemanusiaan modern. (Yogyakarta, Pustaka Pelajar, 1997), p.5 
it turns out that each of its social components does not always create relations between humans in a godly, civilized, just and humane manner. Some of them even show behavior such as being godless or according to a philosopher named Nietchze, known as "God is dead" in him. ${ }^{2}$

Some of them even living their life in the wild, immoral, and contrary to religious beliefs. They choose related patterns and lifestyle that undermine human dignity, because the life that they choose is characterized by savagery, winning over thecharacter of homo-animalism (worshiping animalistic passion) and not promoting the values of civilization.

Violence, harassment, and sexual exploitation do not only affect adult women, but also a woman who are classified as minors (children). This sexual crime also does not only take place in a corporate environment, offices in certain places that provide opportunities for people of different types to communicate with each other but can also occur in the family environment. Violence is not only an individual issue or a national issue but is a global, and even transnational issue. ${ }^{3}$

It is quite concerning since the tendency for the increasing number of sexualcrimes not only affect adult women, but also underage children. Children are the potential as well as the continuation of the nation's desire that the previous generations have put 4 child protection, as one of the guarantees of human rights is a real manifestation of the regeneration of a country's development. 5

Girls are used as objects of commodities (trade) or to satisfy the lecherous (animalistic) desires of certain individuals and groups who run sexual businesses in order to gain multiple economic benefits. The reality shows that in the community there has been a lot of violence that has resulted in many victims recently. Likewise, cases of child abuse as victims at the Bali Police that found in the preeliminary research as follows:

\section{Table 1. Data of Child Violence as Victims}

\begin{tabular}{|c|c|c|c|c|c|c|c|}
\hline \multirow{2}{*}{ No } & \multirow{2}{*}{ Year } & \multicolumn{4}{|c|}{ Types of Crime } & \multirow{2}{*}{ Amount } & Completed \\
\cline { 3 - 6 } & & $\begin{array}{c}\text { Physical } \\
\text { Abuse }\end{array}$ & Fornication & Intercourse & Others & & \\
\hline 1 & 2017 & 45 & 25 & 38 & 25 & 133 & 129 \\
\hline 2 & 2018 & 40 & 26 & 39 & 12 & 117 & 106 \\
\hline 3 & 2019 & 41 & 45 & 36 & 24 & 146 & 101 \\
\hline
\end{tabular}

Source : Directorate General Crime Agency of Bali Regional Police 2019

Types of crime, i.e:

1. Child abuse;

2. Fornication of Child;

2 Wahid Abdul \& Irfan Muhammad, (2001), Perlindungan Korban Kekerasan Seksual, Refika Aditama, Bandung, p.5.

3 Pasalbessy, Jhon D. "Dampak tindak kekerasan terhadap perempuan dan anak serta solusinya." Jurnal Sasi 16, no. 3 (2010).

4 Mastur, Mastur, Syamsuddin Pasamai, and Abdul Agis. "Perlindungan Hukum Terhadap Anak Korban Kekerasan Seksual." Journal of Lex Philosophy (JLP) 1, no. 1 (2020): 137-150.

5 Arliman, Laurensius. "Reformasi Penegakan Hukum Kekerasan Seksual Terhadap Anak Sebagai Bentuk Perlindungan Anak Berkelanjutan." Kanun Jurnal Ilmu Hukum 19, no. 2 (2017): 305-326. 
3. Copulation with Child;

4. Abduction of Child;

5. Criminal act of people-trafficking;

6. Child Abandonment;

7. Child Discrimination;

8. Taking away Child.

The issue of child protection is something complex and raises various kinds of further problems, which cannot always be solved individually but must be solved collectively, and whose resolution is a common responsibility among us. The legal protection for children is provided so the children's rights are protected as stated in the laws and regulations concerning child protection. ${ }^{6}$

Child protection is a result of interaction between existing phenomena and influencing each other. Child protection is closely related to the five pillars, namely, parents, family, community, government, local, and state governments. 7 Therefore, whether we want to be aware of the existence of, good or bad, proper or inappropriate child protection, we must pay attention to the relevant phenomena, which have an important role in the occurrence of child protection activities. To develop child protection activities, we must be vigilant and aware of the unwanted consequences that cause victims, losses due to irrational, positive, irresponsible, and useless implementation of child protection. Hence, it must be endeavored to have something that regulates and guarantees the implementation of child protection. It must be prevented so that the various arrangements for child protection efforts do not guarantee the existence of child protection and even cause various other negative deviations.

\section{Research Method}

This is an empirical juridical legal study since "in this research is based on the existing theories and is also compared with research based on interviews and data in the field". 8 This research uses a sociological a pproach, a statutory a pproach, a conceptualapproach, and a case approach. The data used are primary data and secondary data. The primary data is obtained from the field through interviews. While, the secondary data is obtained through library research in the form of primary, secondary, and tertiary legal materials. The analysis technique used in this research is descriptive qualitative analysis.

\section{Result and Discussion}

\subsection{The Legal Protection Given to the Children as Victims of Sexual Violence at the} Directorate General Crime Agency of Bali Regional Police

Legal protection is protecting human rights that have been harmed by other and the protection is given to the community so that they can enjoy all the rights provided by law or in other words, legal protection is various legal measures that must be provided by law enforcement officials to provide a sense of security, both physically and mentally from disturbances and various threats from any party.

6 Anggara, Gede Nyoman Gigih, and Made Subawa. "PERLINDUNGAN HUKUM TERHADAP ANAK SEBAGAI KORBAN KEKERASAN." Kertha Wicara: Journal Ilmu Hukum: $1-14$.

7 Fitriani, Rini. "Peranan Penyelenggara Perlindungan Anak Dalam Melindungi Dan Memenuhi Hak-Hak Anak." Jurnal Hukum Samudra Keadilan 11, no. 2 (2016): 250-358.

8 Sunggono Bambang, (2007), Metodelogi Penelitian Hukum, PT. Raja Grafindo, Jakarta, p. 44. 
According to Setiono, Legal protection means " actions or efforts to protect society from arbitrary actions by the authorities who are not following the rule of law, to create order and peace to enable humans to enjoy their dignity as human beings". ${ }^{9}$

Based on Indonesian Dictionary (namely KBBI) defines that legal protection is as a place of refuge, actions (things and so on) protect. The linguistic meaning of the word protection has similar elements, namely the element of protective action, the element of protective methods. Thus, the word protects from certain parties by using certain means. 10

The protection for children in conflict with the law includes children who conflict with the law and children who are victims of criminal acts. They are the responsibility of the government and society. Child protection currently does not fully reflect handling using a restorative justice approach. ${ }^{11}$

The special protection for children in conflict with the law is carried out through:

a. Humane treatment of children in accordance with the dignity and rights of the child;

b. Provision of special companion officers for the children from an early age;

c. Provision of special facilities and infrastructure;

d. Imposing appropriate sanctions in the best interests of the child;

e. Continuous monitoring and recording of the development of children in conflict with the law;

f. Guarantee to maintain relationships with parents of family; and

g. Protection from reporting identity through the mass media and to avoid labeling.

Related to the increasing prevalence of sexual violence against children, especially in the jurisdiction of the Bali Regional Police, Mrs. Siti Sapurah said: Broadly speaking, sexual violence against children must receive serious attention from the state and the government, especially in the Bali Regional Police. The fact that there are many cases of sexual violence against children indicates that they tend to lack attention, protection, and are often neglected." 12 Sexual abuse of children leads to sexual violence which includes sexual harassment, sexual control, rape, sexual exploitation, sexual torture, which is contrary to the principle of human rights that must be protected.

Sexual abuse of children leads to sexual violence, which includes sexual harassment, sexual control, rape, sexual exploitation, sexual torture, which is contrary to the principles of human rights that must be protected. 13 The cases of sexual violence against children are increasing, the causes are:

a. Internal factors: parenting patterns and parenting styles are the main factors for child development. As much as possible, parents, especially mothers, from

9 Setiono, (2004), Supremasi Hukum, UNS, Surakarta, p. 3.

10 Dani K, (2002), Kamus Besar Bahasa Indonesia (KBBI), Edisi Kedua, Cet. 1, Balai Pustaka, Jakarta, p. 595.

11 Aprilianda, Nurini. "Perlindungan anak korban kekerasan seksual melalui pendekatan keadilan restoratif." Arena hukum 10, no. 2 (2017): 309-332.

12 Aryani, Nyoman Mas. "Perlindungan Hukum terhadap Anak sebagai Korban Kekerasan Seksual di Provinsi Bali." Kertha Patrika 38, no. 1 (2016).

13 Budiarta, I. Wayan, and I. Gusti Ngurah Parwata. "Perlindungan Hukum Terhadap Anak Dan Perempuan Selaku Korban Kejahatan Seksual." Kertha Wicara: Journal Ilmu Hukum 8, no. 6: 115. 
an early age introduce the child's privacy areas that should not be seen and touched by others except the child himself. Introduce the children about their bodies and how to protect them from sexual crimes.

b. External factor: the communication and association of children outside the home continue to receive supervision from their parents. Supervise our children while playing with gadgets because with the development of technology it is easier for children to access pornographic contents and if it does not get any supervision and advice from their parents, the child will grow and develop according to what he sees as well when the children watch television, the parents also need to accompany their children as much as possible. ${ }^{14}$

In term of children from minority groups and isolated need special protection. It is carried out through the provision of infrastructure and facilities so the children with special needs can enjoy their own culture and use their language. Besides, it prohibitsall actions that are intended to obstruct the exercise of these children's rights.

Special protection for children who are exploited economically and/or sexually is an obligation and responsibility of the government and society. The protection of children who are exploited is carried out through:

1. Disseminating and/or socialization of the provisions of laws and regulations relating to the protection of children who are exploited economically and/or sexually;

2. Monitoring, reporting, and imposing sanctions; and

3. Involving various government agencies, companies, trade unions, nongovernmental organizations, and communities in the elimination of exploitation of children economically and/or sexually.

To protect the interests of those children, the laws and regulations prohibit anyone from placing, allowing, doing, ordering, or participating in exploiting children as referred to in this law.

The child kidnapped victims, selling and trafficking are carried out through government, and community supervision, protection, prevention, treatment, and rehabilitation efforts. The law prohibits anyone who places, permits, carries out, orders, or participates in the kidnapping, sale or trafficking of the child. The protection for child victims are carried out through:

1. Disseminating and socialization of the provisions of the law and regulations relating the protection of children who are exploited economically and/or sexually;

2. Monitong, reporting and imposing sanctions.

The law prohibit everyone from placing, allowing, doing, ordering to do, or participating in violence as intended by this law. The special protection for children with dissabilities is carried out through:

1. Treating children humanely according to the gisnity and rights of the child;

2. Meeting their special needs; and

3. Receive the same treatment as other children in order to achieve the full possible special integration and individual development.

14 Interview with Mrs. Siti Sapurah, Advocate (Child Observer), on August 10, 2020. 
The law prohibits everyone from treating children regardless of their views in a discriminatory manner, including labeling and equalizing education for children with disabilities.

Special protection for children victims of abuse and neglect is carried out through supervision, prevention, treatment, and rehabilitation by the government and the community. The law prohibits everyone from placing, allowing, involving, asking to involve any children in situations of mistreatment and neglect.

Children victims of mistreatment and neglect Special protection for children victims of abuse and neglect is carried out through supervision, prevention, treatment and rehabilitation by the government and the community. The law prohibits everyone from placing, allowing, involving, asking to involve children in situations of mistreatment and neglect.

The special treatment is also carried out for children in emergency situations such as:

a. Children who become refugees;

b. Child victims of riots;

c. Child victims of natural disasters; and

d. Children in gun conflict situations.

Special treatment for children who become refugees is carried out through the provision of humanitarian law, while the special protection for child victims of riots, child victims of natural disasters, and children in gun conflict is carried out through:

a. Fulfilling the basic needs consist of food, clothes, house, education, health, learning and recreation, security assurance, and equality of treatment;

b. Fulfilling the special needs of children with disabilities and children with psychosocial disorders, such as psychological trauma and early childhood developmental disorders.

Everyone is prohibited from recruiting or using children for military and/ot other purpose and leaving the children without life protection.

\subsection{Legal Action Taken When Legal Protection of Child as Victims is not Implemented}

The problem of immoral crimes against children arises since the enforcement of criminal law has not been oriented towards the value of justice, especially the protection of victims but rather on the application of punishment to the perpetrator. ${ }^{15}$ Affirmative measures to protect children need to be taken since they belong to a weak and vulnerable group. ${ }^{16}$ The realization of the protection of children as victims of criminal acts has not been maximized because the rights of victims to receive rehabilitation, compensation and restitution are still difficult in terms of the process of handling them. ${ }^{17}$ The Criminal Code Procedure (known as KUHAP) pays less attention in terms of victims of crime, especially victims of rape, as the most disadvantaged parties who also need protection of their rights that have been violated. Most of the time the involvement of victims in the

15 Wahyuningsih, Sri Endah. "Perlindungan Hukum Terhadap Anak Sebagai korban Tindak Pidana kesusilaan dalam Hukum Pidana Positif Saat Ini." Jurnal Pembaharuan Hukum 3, no. 2 (2016): 172-180.

16 Handayani, Trini. "Perlindungan Dan Penegakan Hukum Terhadap Kasus Kekerasan Seksual Pada Anak." Jurnal Hukum Mimbar Justitia 2, no. 2 (2018): 826-839.

17 Dwiatmodjo, Haryanto. "Pelaksanaan Perlindungan Hukum terhadap Anak yang Menjadi Korban Tindak Pidana di Wilayah Hukum Pengadilan Negeri Banyumas." Jurnal Dinamika Hukum 11, no. 2 (2011): 201-213. 
criminal justice system only adds to lingering fear, helplessness, and disappointment at not being given adequate protection.

As in the case of sexual harassment of his biological children and grandchildren, which received the attention of many people, Aris Tri Muntiyani explained as follows: "The perpetrator of sexual harassment according to the Civil Code can be sued for compensation both materially and spiritually because both the parent and his grandfather who were the perpetrators were also detained according to the decision, the compensation claim is temporarily suspended." 18

Even though Law Number 39 the Year 1999 concerning Human Rights has stated about children's rights, the implementation of the obligations and responsibilities of parents, family, society, government, and the State to protect children, the urgency of law on child protection is still required as a basis juridical for the implementation of these obligations and responsibilities. Thus, the formation of this law is based on the consideration that child protection in all its aspects is part of national development activities, especially in advancing the life of the nation and state.

Parents, families, and communities are responsible for safeguarding and maintaining these human rights following the obligations imposed by Law. Likewise, in the context of implementing child protection, the State and government are responsible for providing facilities and accessibility for children, especially in ensuring their optimal and targeted growth and development.

The law emphasizes that the responsibility of parents, family, community, government, and the State is a series of activities carried out continuously for the protection of children's rights. The series of activities must be continuous and directed in order to ensure the growth and development of children, both physically, mentally, spiritually, and socially. This action is intended to create the best life for children who are expected to be the nation's potential successors, tough, nationalism imbued with noble morals and values of Pancasila, and have a strong will to maintain the unity of the nation and State.

Child protection efforts need to be implemented as early as possible, from the fetus in the womb to the child aged 18 (eighteen). Starting from a complete, thorough, and comprehensive conception of child protection, this law sets out the obligation to protect children based on the following principle:

a. Non-Discrimination;

b. Best interests of the child;

c. Right to life, survival, and development; and

d. Respect for children's opinions. ${ }^{19}$

In providing guidance, development, and protection of children, the role of the community is needed, either through child protection institutions, religious institutions, non-governmental organizations, community organizations, social organizations, the business world, mass media, or educational institutions. The form of legal protection assistance, monitoring, advocacy provided is regulated in the child protection law. ${ }^{20}$

18 Interview with Mrs. Haris Tri Muntiyani, Social Worker of the Bali Province Social Service, on August 10, 2020.

19 Gultom Maidin, (2008), Perlindungan Hukum Terhadap Anak, Refika Aditama, Jakarta, p. 33.

20 Lubis, Elvi Zahara. "Upaya Perlindungan Hukum Terhadap Anak Korban Kekerasan Seksual." JUPIIS: JURNAL PENDIDIKAN ILMU-ILMU SOSIAL 9, no. 2: 141-150. 
In Law Number 35 of 2014 concerning Amendments to Law Number 23 of 2002 concerning Child Protection, it is explicitly and stipulated that criminal provisions against acts that violate the law against children.

The provisions referred to have been regulated from Article 76 A to 89 as follows: "Anyone who deliberately takes action:

a. Discrimination against children which results in children experiencing losses, both materially and morally, thereby hindering their social function; or

b. Neglect of a child that causes the child to experience pain or suffering, whether physical, mental, or social shall be sentenced to imprisonment of up to 15 (fifteen) years and/or a maximum fine of $\operatorname{Rp~5,000,000,000~(five~billion~}$ rupiah)." 21

\section{Conclusion}

Legal protection provided for children as the victims of sexual violence at the Directorate General Crime Agency of Bali Regional Police, includes humane treatment of children according to the child's dignity and rights, excellent service, humanist and professional with a sympathetic and empathetic attitude, Provision of special companion officers children from a social worker from the Social Service, Child health checks, implementation of vaginal swab and post-mortem to find out about the treatment of the child's limbs, especially on the genitals of children victims of sexual violence, providing psychological counseling, Provision of special facilities and infrastructure for child examination, Provision of housing safe (known as shelter) for child victims of violence, providing restitution to child victims of sexual violence, imposing appropriate sanction for the best interests of the child, continuous monitoring, and recording of the development of the children who are victims of violence, and protection from reporting the identity of victims through the mass media and to avoid labeling. The legal remedies that can be taken if the legal protection for child victims of violence is not implemented if, during the investigation stage, the victim feels that he does not receive legal services or protection from the investigator regarding the rights of the performance can be evaluated to be able to provide maximum legal services and protection to children. In the term that the perpetrator of the crime is a child whose case is resolved through the Diversion process, if the diversion agreement is not implemented within a predetermined time, the Community Advisor reports in writing to the investigator's direct supervisor to be followed up in the criminal justice process with a copy to the head of the local district court.

\section{References}

\section{$\underline{\text { Books }}$}

Dani K, Kamus Besar Bahasa Indonesia (KBBI), Edisi Kedua, Cet. 1, (Jakarta, BalaiPustaka, 2002)

Gultom Maidin, Perlindungan Hukum Terhadap Anak, (Jakarta, Refika Aditama, 2008). Nashir Haedar, Agama Dan Krisis Kemanusiaan Modern, (Yogyakarta, Pustaka Pelajar, 1997).

Setiono, Supremasi Hukum, (Surakarta, UNS, 2004).

Sunggono Bambang, Metodelogi Penelitian Hukum, (Jakarta, PT. Raja Grafindo, 2007).

21 Interview with Mrs. Siti Sapurah, Advocate (Child Observer), on August 10, 2020. 
Wahid Abdul \& Irfan Muhammad, Perlindungan Korban Kekerasan Seksual, (Bandung, Refika Aditama, 2001).

\section{Journals}

Anggara, Gede Nyoman Gigih, and Made Subawa. "PERLINDUNGAN HUKUM TERHADAP ANAK SEBAGAI KORBAN KEKERASAN." Kertha Wicara: Journal Ilmu Hukum: 1-14.

Aprilianda, Nurini. "Perlindungan anak korban kekerasan seksual melalui pendekatan keadilan restoratif." A rena hukum 10, no. 2 (2017): 309-332.

Aryani, Nyoman Mas. "Perlindungan Hukum terhadap Anak sebagai Korban Kekerasan Seksual di Provinsi Bali." Kertha Patrika 38, no. 1 (2016).

Arliman, Laurensius. "Reformasi Penegakan Hukum Kekerasan Seksual Terhadap Anak Sebagai Bentuk Perlindungan Anak Berkelanjutan." Kanun Jurnal Ilmu Hukum 19, no. 2 (2017): 305-326.

Budiarta, I. Wayan, and I. Gusti Ngurah Parwata. "Perlindungan Hukum Terhadap Anak Dan Perempuan Selaku Korban Kejahatan Seksual." Kertha Wicara: Journal Ilmu Hukum 8, no. 6: 1-15.

Dwiatmodjo, Haryanto. "Pelaksanaan Perlindungan Hukum terhadap Anak yang Menjadi Korban Tindak Pidana di Wilayah Hukum Pengadilan Negeri Banyumas." Jurnal Dinamika Hukum 11, no. 2 (2011): 201-213.

Fitriani, Rini. "Peranan Penyelenggara Perlindungan Anak Dalam Melindungi Dan Memenuhi Hak-Hak Anak." Jurnal Hukum Samudra Keadilan 11, no. 2 (2016): 250358.

Handayani, Trini. "Perlindungan Dan Penegakan Hukum Terhadap Kasus Kekerasan Seksual Pada Anak." Jurnal Hukum Mimbar Justitia 2, no. 2 (2018): 826-839.

Lubis, Elvi Zahara. "Upaya Perlindungan Hukum Terhadap Anak Korban Kekerasan Seksual." IUPIIS: IURNAL PENDIDIKAN ILMU-ILMU SOSIAL 9, no. 2: 141-150.

Mastur, Mastur, Syamsuddin Pasamai, and Abdul Agis. "Perlindungan Hukum Terhadap Anak Korban Kekerasan Seksual." Journal of Lex Philosophy (JLP) 1,no.1 (2020): 137-150.

Pasalbessy, Jhon D. "Dampak tindak kekerasan terhadap perempuan dan anak serta solusinya." Jurnal Sasi 16, no. 3 (2010).

Wahyuningsih, Sri Endah. "Perlindungan Hukum Terhadap Anak Sebagai korban Tindak Pidana kesusilaan dalam Hukum Pidana Positif Saat Ini." Jurnal Pembaharuan Hukum 3, no. 2 (2016): 172-180.

\section{Law and Regulation}

Undang-Undang Nomor 35 tahun 2014 tentang Perubahan atas Undang-Undang Nomor 23 Tahun 2002 Tentang Perlindungan Anak

Undang-Undang Nomor 4 tahun 1979 tentang Kesejahteraan Anak

Peraturan Presiden Republik Indonesia Nomor 61 Tahun 2016 tentang Komisi Perlindungan Anak Indonesia 